\title{
From sustainable to smart: Re-branding or re- assembling urban energy infrastructure?
}

Darcy Parks and Harald Rohracher

The self-archived postprint version of this journal article is available at Linköping University Institutional Repository (DiVA):

http:/ / urn.kb.se/ resolve?urn=urn:nbn:se:liu:diva-154626

N.B.: When citing this work, cite the original publication.

Parks, D., Rohracher, H., (2019), From sustainable to smart: Re-branding or re-assembling urban energy infrastructure?, Geoforum, 100, 51-59. https:// doi.org/ 10.1016/j.geoforum.2019.02.012

Original publication available at:

https:// doi.org/ 10.1016/j.geoforum.2019.02.012

Copyright: Elsevier (24 months)

http://www.elsevier.com/

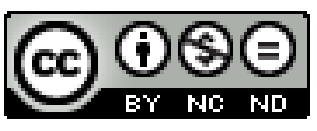




\title{
From sustainable to smart: Re-branding or re-assembling urban energy infrastructure?
}

\begin{abstract}
Visions of sustainable cities have increasingly been substituted by the ambition to become a 'smart city' in recent years. Ongoing scholarly discussions often focus on how sustainability and 'smartness' relate to each other conceptually, to which extent smart city technologies contribute to making cities more sustainable, and calls to prioritise social issues over technology. The questions of how this 'shift to smart' has unfolded, and how it has reshaped strategies and interventions to make cities and their energy infrastructures more sustainable, have however been much less investigated. The aim of this article is to zoom in on the dynamics of such a shift from sustainable to smart. The cities of Malmö and Graz have strong profiles as sustainable cities and have both begun to use smart city branding. We build our analysis on argumentative discourse theory and the concept of sociomaterial assemblages. Along with a discursive shift from sustainable cities to smart cities, we also observe changes in institutions and socio-material practices. We identify appropriation and colonisation as two dynamics that characterise the relations between assemblages of sustainable and smart cities. We conclude that even when smart city discourses are appropriated by actors in existing sustainable city assemblages, the discursive shift might eventually allow smart city assemblages to colonise existing institutions and socio-material practices. But the shift does not take place through explicit controversy between two discourse coalitions, and it therefore remains important to further investigate the conditions that allow for a change in dynamics from appropriation to colonisation.
\end{abstract}

Keywords: sustainable cities; smart cities; ICT; discourse analysis; discourse coalitions; assemblage 


\section{Introduction}

Visions and programmes of sustainable or green cities have increasingly been substituted by the ambition to become a 'smart city' in recent years (de Jong et al., 2015; European Parliament, 2014). Ongoing scholarly discussions often focus on how sustainability and 'smartness' relate to each other conceptually (Martin et al., 2018), to which extent smart city technologies can contribute to making cities more sustainable (Höjer and Wangel, 2015), and calls to prioritise citizens and social issues over technology (Cowley et al., 2017; Hajer, 2015). The questions of how this 'shift to smart' has unfolded, and how it has reshaped strategies and interventions to make cities and their energy infrastructures more sustainable, have however been much less investigated. Are smart city discourses being used to re-brand sustainability interventions without much change in practice, for example to attract additional funding from higher levels of government? Or do smart discourses reflect a re-assembling of socio-material relations in cities that qualitatively changes existing practices of sustainable urban planning and prioritises other interests and goals?

Such questions are of great interest for our understanding of urban sustainability transitions. They draw attention to the precarious interrelation of visions and discourses of urban change with the emergence of new socio-material practices in cities. While sustainable and smart can both be defined in many ways and are contested concepts, different sets of socio-material practices are commonly associated with each concept. Sustainable cities are commonly defined by an implementation of sustainability principles as set out in the UN Brundtland report (integration of economic, social and environmental goals) and Local Agenda 21 in an urban context (see Bulkeley and Betsill, 2005; Martin et al., 2018). In the energy field, these principles often find their expression in initiatives focused on low carbon technologies, resource efficiency and renewable energy as exemplified by cities such as Austin, Vancouver or Freiburg (Long, 2016; McCann, 2011; Rohracher and Späth, 2014). These initiatives incorporate sustainable city discourses through spatial planning (Mneimneh et al., 2017; Wretling et al., 2018), energy efficiency standards (Rohracher and Späth, 2014; Smedby, 2016), support to developers (Quitzau et al., 2013; Smedby and Neij, 2013), and renewable energy production (Bulkeley et al., 2014; Dóci et al., 2015). City governments employ diverse modes of governance in these initiatives, and often rely on enabling and intermediary organisations because they lack authority over urban energy systems (Bulkeley and Kern, 2006; Hodson et al., 2013).

In contrast, smart city initiatives often build on the increased use of information and communication technologies (ICT) in urban infrastructures and services (European Parliament, 2014). Examples of these technologies include sensors in urban infrastructure, platforms to store big data, visualisation technologies for individuals, and operations centres for city governments (Kitchin, 2014). The implementation of these technologies in energy infrastructures, for example as smart grids, is often linked to promises of making energy demand more flexible and of using resources more efficiently (Strengers, 2013). There are a few high profile initiatives that have come to exemplify smart cities, both in media and research, such as Rio de Janeiro, Songdo and Masdar City (Kitchin, 2015). Social science researchers have criticised these example initiatives, along with other uses of smart city discourses, for several potential impacts: the corporatisation of urban governance by outsourcing increasing parts of city management to large ICT companies; the prioritisation of ICT solutions over other urban issues; increased surveillance; and decreased reliability of urban infrastructure (Gabrys, 2014; Kitchin, 2014; Söderström et al., 2014; Vanolo, 2014). Other studies of specific initiatives criticise smart cities for being empty rhetoric (Crivello, 2015; Wiig, 2016), but nevertheless help to explain the appeal of smart city discourses - they appeal to politicians and policy makers because they help to attract funding and attention to a city. 
A few studies have already empirically explored the impacts that smart city discourses have on urban environmental policies and the governance of energy infrastructures. These studies provide some ideas about how the shift to smart might occur, including the potential impacts of corporatisation and the prioritisation of ICT solutions. Haarstad (2017) studies the relation between European Union smart city policies and actual projects implemented in the Norwegian city of Stavanger. He shows that local sustainability challenges were more dominant than smart technology discourses, leading to projects that implemented "relatively low-tech solutions" (p. 13). He concludes that there are different factors that explain the appeal of smart city discourses in sustainable urban planning: technological solutions provide hype despite lacking empirical evidence of sustainability benefits; the flexibility of the smart city discourse provides political opportunities; and governance innovations allow for new forms of collaboration and problem solving. Two other studies also conclude that smart city discourses lead to what could be called governance innovations, which can take the form of the privatisation of energy infrastructure or a blurring of distinctions between public and private authority (March and Ribera-Fumaz, 2016; McLean et al., 2016). Bulkeley et al. (2016) point out that the actualisation of smart city discourses is intertwined with urban material politics that moderate the influence of even the most well-funded and politically backed projects.

The aim of this article is to zoom in on the dynamics of such a shift from sustainable to smart: how both discourses co-exist and how their co-existence creates new tensions and dynamics of change. We investigate this shift in the context of cities with well-known traditions of sustainable urban development. Our objects of study are two cities with strong profiles as sustainable cities and eco-cities, which have put much emphasis on environmental policy and sustainability initiatives during the 1990s and 2000s: Malmö, Sweden, and Graz, Austria. More recently, these city governments have begun to use the term 'smart city', both in relation to specific city districts and for the whole city. We analyse how this new branding influences sustainability measures and whether this change has been accompanied by continuities or disruptions of existing practices. Is the smart city discourse in these cities only an empty signifier, pushed as part of a marketing and re-branding process? Or does the introduction of this discourse actually re-configure socio-material relations around the built environment and energy systems?

In the remaining part of this paper, we will investigate these questions based on an empirical analysis of the cities of Malmö and Graz. In the next section, we will develop the theoretical approaches used to analyse the shift from sustainable to smart: argumentative discourse analysis and assemblage theory. Section 3 describes research methods. Sections 4 and 5 then analyse the empirical material of the two cases, followed by a comparative discussion (section 6 ) and conclusions (section 7).

\section{Theoretical framework: discourses and urban socio- material change}

The shift to smart is an elusive object of study given that there is no consensus on what it means for a city to be smart, and the often rather indirect ways and long time horizons through which smart city discourses might influence urban governance. However, the ambiguity and contestedness of the smart city discourse is a trait it shares with other discourses, including the sustainable city discourse that is also central to this article. Our theoretical perspective uses the concept of discourse as a starting point. We extend the theory of argumentative discourse analysis with assemblage theory to put more emphasis on the socio-material processes implicated in the shift to smart. 
Hajer's (1997) theory of argumentative discourse analysis, prominent in the study of environmental governance, conceives of political struggles as an argumentative game between different discourse coalitions who aim for dominance. Each discourse coalition is an "ensemble of (1) a set of story-lines; (2) the actors who utter these story-lines; and (3) the practices in which this discursive activity is based" (Hajer, 1997, p. 65). As one discourse coalition progresses in this discursive struggle, use of its discourse becomes necessary for actors to maintain their credibility; when the discourse prevails, it "is translated into institutional arrangements," which Hajer calls the condition of discourse institutionalisation (p. 61). This theory is relevant for understanding existing sustainable city initiatives, which are also based on story lines such as climate change, actor constituencies such as city governments, utility companies and civil society initiatives, and practices such as encouraging energy efficiency and renewable energy. One aspect lacking from this definition is the wealth of the material elements that are deeply entangled with sustainable city discourses and contribute to their stabilisation and enactment in concrete urban socio-material practices: urban energy infrastructure, buildings and their energy efficiency technology, and city districts whose sustainability qualities contribute to a city's green profile. Sustainability discourses in the two cities we investigate have already reached some level of discourse institutionalisation, with strong networks of actors and new institutions such as a local energy agency in Graz (Rohracher \& Späth, 2014), institutionalised developer dialogues in Malmö (Smedby, 2016), and sustainability action programmes in both cities. A core question we ask in this paper is how the new discourse of smart cities changes the terms of the sustainability discourse and creates new openings and contested situations.

We address the materiality entangled with discursive change by drawing on a growing literature that applies the concept of assemblage to urban studies. An assemblage perspective "conceives of cities as ensembles of heterogeneous actors, giving analytical priority to the active dynamics of arranging or fitting together socio-material elements" (Blok, 2013, p. 8). This idea of heterogeneous actors encompasses discourses and story lines, actors and the coalitions they form, practices and institutions, and the material world such as infrastructures. With a focus on active dynamics, an assemblage perspective helps to understand how a change in one element affects others. For example, building a new green city district might shape and stabilise a sustainable city discourse in particular ways and provide legitimacy; conversely, the loss of support for a sustainable city discourse might lead to new practices and less sustainable urban infrastructure. Discourses, discourse coalitions and institutions remain relevant in our perspective, but as elements in assemblages that also contain other elements.

To understand the emergence of smart city discourses in a city, we draw on the assemblage theory of Manuel DeLanda (2016, 2006). In DeLanda's terms, we are studying the territorialisation of smart city assemblages. Despite the geographical metaphor, he explains that the process of territorialisation "refers not only to the determination of the spatial boundaries of a whole ... but also to the degree to which an assemblage's component parts are drawn from a homogenous repertoire, or the degree to which an assemblage homogenises its own components" (DeLanda, 2016, p. 22). Assemblage theory and discourse complement each other. While discourse institutionalisation speaks to the processes of normalising and embedding of discourses in social structures, territorialisation brings in the material elements which contribute to this normalisation. Assemblage theory involves a "general emphasis on flux, contingency and dynamism, and to uncovering the multiple movements that together constitute an effect" where "the process of assembling, rather than the assemblage as resultant formation is therefore prioritised conceptually" (Williams, 2018, pp. 33-34). Studying the shift to smart involves an analysis of the process through which these cities might become home to assemblages whose constitutive parts are homogeneously 
drawn from a smart city repertoire made up of discourses and material elements. Prior to this shift, we would not be able to identify a smart city as assemblage of any homogeneity. Instead, in these cities with established sustainable city initiatives, we would expect to find sustainable city assemblages with relatively high degrees of territorialisation.

In asking whether smart city initiatives involve a re-branding or re-assembling of urban energy infrastructure, we express an interest in not only the territorialisation of smart city assemblages, but also any resulting changes or destabilisation of sustainable city assemblages-not just at the discursive level but also their socio-material underpinnings. Whether territorialisation of one assemblage leads to deterritorialisation of another is an empirical question, as "one and the same assemblage can have components working to stabilise its identity as well as components forcing it to change or even transforming it into a different assemblage" (DeLanda, 2006, p. 12). An additional advantage of this perspective in relation to a purely argumentative discourse analysis is the recognition of co-existing multiplicities beyond rather dichotomous discursive struggles. An assemblage perspective is well suited to understanding how multiple assemblages "collide with each other, overlap, interfere, and form thereby a multiplicity that has to be managed, coordinated, or even held apart" (Farías, 2010, p. 14; with reference to Mol, 2002). While we expect to see ways in which smart city assemblages interfere with sustainable city assemblages, we might also find ways in which they overlap without conflict, at least for limited periods of time.

In the two cases analysed below, we apply this theoretical framework by analysing change in two assemblages: a sustainable city assemblage and a smart city assemblage. The process of assembling observed in the two cases encompasses the weaving together of heterogeneous networks of discourses, actors, institutions and socio-material practices; the composition of each assemblage varies over time. While an overlap emerges between the assemblages, that is not the same as saying that they become part of one large assemblage. What makes the assemblages distinct is that they draw on different repertoires. Nevertheless, as we will show, the changes to these assemblages are not independent of each other but involve different types of interrelations. This perspective allows us to trace the emergence of smart city assemblages as well as the resulting changes to existing sustainable city assemblages.

\section{Method}

This article builds on a case study of smart city initiatives in each city. For Malmö, the article's first author interviewed and did participant-observation from June 2014 to September 2016. The interviews involved employees at various city departments, property development companies, Eon and the Swedish Energy Agency. The participant-observation concerned monthly meetings between city departments and Eon in their work in a new city district named Hyllie. The article also builds on public documents from the City of Malmö, Eon and the Swedish Energy Agency. The article's second author also participated in a workshop with Eon employees in October 2017. For Graz, the article's second author has previously studied sustainable city initiatives in the city (e.g. Rohracher \& Späth, 2014) and carried out six additional interviews with main actors in the development of the new districts with smart city branding. These interviews took place between December 2016 and May 2017; they included actors such as the city councillor responsible for environmental issues, the architect responsible for the smart city development, and the head of the municipal utilities. The two authors separately analysed the empirical material for each city to identify important moments in the shift to smart. 

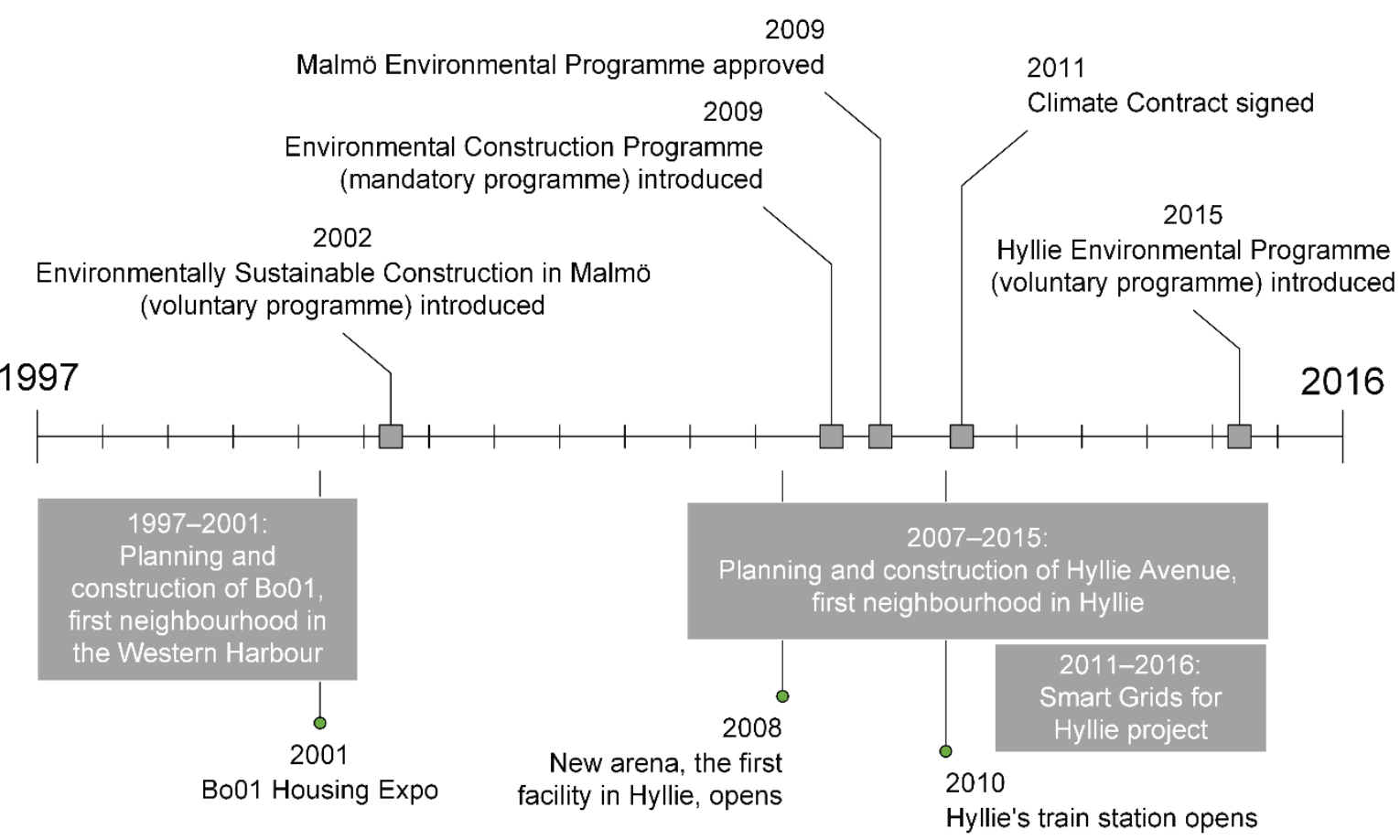

\section{Malmö: from sustainable to climate-smart}

Malmö has a worldwide reputation as a sustainable city that dates back to a city district called the Western Harbour, where construction began in the late 1990s. The city administration's experiences in the Western Harbour helped it develop practices of sustainable urban planning. The next large development project in Malmö was a city district named Hyllie, where construction of a commercial centre took place between 2005 and 2010. Smart city discourses gained increasing importance in Hyllie. In adopting smart city discourses, the city administration collaborated with Eon, the energy utility that owns and operates Malmö's energy infrastructure. (Figure 1 shows a timeline of important events and policies in Malmö.)

Malmö's profile as a sustainable city originated in the city government's efforts to reinvigorate the city after an economic downturn. The Western Harbour was previously the site of a shipyard and other factories that closed during the 1980s and 1990s. In its efforts to transform the city, the city government lobbied for a new university, and in 2001 it organised a housing exhibition in the first neighbourhood of the Western Harbour. The exhibition had a sustainability focus and it contributed to an emerging story line about Malmö as a leader in sustainable urban planning. City planners engaged Sydkraft, the local energy utility that Eon would later acquire, in setting ambitions for the energy system in this neighbourhood (Green, 2006). Property developers also agreed to a quality programme that aimed to "ensure that the neighbourhood's environmental profile is of high quality so that it becomes an internationally leading example of how environmental accommodation of densely built areas can act as a motor in Malmö's transition to environmental sustainability" (City of Malmö, 2002a, p. 5). Over 15 years later, the Western Harbour was still attracting study visits as an example of sustainable urban planning. These agreements with the energy utility and property developers established the first elements of the sustainable city assemblage in Malmö.

After the housing exhibition, the sustainable city assemblage was further homogenised through the city government's work in other new neighbourhoods and with new planning programmes. In 2002, the city government published a programme called Ecologically Sustainable Figure 1: Timeline of important events and policies in Malmö 
Construction in Malmö that contained sustainability recommendations for developers (City of Malmö, 2002b). In the neighbourhoods of the Western Harbour that followed the housing exhibition, the city administration continued to lead dialogue processes with groups of property developers. According to one city planner with experience from several neighbourhoods, these developer dialogues began at different times in relation to the spatial planning process, allowing planners to experiment and gain experience about when it was best to get input from developers (interview, June 2014). Based on its experience, the city government later developed the Environmental Construction Programme in collaboration with researchers and a neighbouring municipality (City of Malmö et al., 2009). This programme set regulations for buildings, but also defined higher standards that developers could aim to achieve. In terms of sustainability, it provided regulations and standards for energy efficiency and urban biodiversity. These programmes and dialogue practices supported the sustainable city discourse and established a relatively homogenous sustainable city assemblage in Malmö. As each neighbourhood was built, the assemblage took additional material form and provided more support to this discourse.

The city government first began drawing on smart city discourses in 2009, when it approved a new version of the Malmö Environmental Programme (MEP). It was in this document that the city government introduced the concept of a 'climate-smart city', as part of the vision that Malmö would become "Sweden's most climate-smart city" by 2020 (City of Malmö, 2009, p. 7). But aside from this new concept, the MEP was very much in line with existing sustainable city assemblage's story line about Malmö being a leader in sustainable urban planning. The programme stated that "in 2020 Malmö's own organisation will be climate-neutral, and in 2030 all of Malmö will be provided by $100 \%$ renewable energy" (p. 7). Energy efficiency was part of this vision in terms of a goal to reduce per capital energy use. Other goals were more renewable energy, reduced greenhouse gas emissions, changes to transportation habits, and climate adaptation. But the MEP did not introduce any additional story lines from smart city discourses, such as the role of ICT; it only borrowed the smart city term in introducing the concept of a climate-smart city. In this sense, the MEP contributed rather little to territorialising a smart city assemblage.

The first institutional and material aspects of a smart city assemblage came in a new city district called Hyllie. Hyllie was a new city district in the south of the city, built on agricultural land located within the ring road that surrounds Malmö. Planning for this district began in the mid-2000s, after the national government's decision to build a new railway tunnel under Malmö with a station in the middle of Hyllie. Around the time that city council approved the MEP, city planners began negotiating an agreement that would become the Climate Contract for Hyllie. The Climate Contract was a vision for Hyllie created in 2011 by a new coalition of actors: the City of Malmö, Eon, and a municipally owned infrastructure company called VA Syd. It envisioned Hyllie as "the most climatesmart city district" in the Malmö-Copenhagen Region, and that Hyllie would "show the way for Malmö's future development as a sustainable city" (City of Malmö et al., 2011, p. 2). The Climate Contract envisioned that Hyllie would be climate-neutral by 2020, but also introduced a smart grid story line about how "energy flows in Hyllie will be supported by smart infrastructure" (p. 3). In terms of its goals for climate change and energy systems, the Climate Contract fit with the sustainable city assemblage; it was also shaped by material elements such as Hyllie's greenfield location at the boundaries of Malmö and its excellent public transport connection. At the same time, it drew on smart city discourses and introduced a story line about the role for ICT and ICT providers in energy infrastructure. The signatories of the Climate Contract emerged as a new discourse coalition and their collaboration established new institutions that began to territorialise the smart city assemblage. 
Shortly after signing the Climate Contract, Malmö and Eon received funding for a project that further territorialised the smart city assemblage. In late 2011, the Swedish Energy Agency granted financial support to the Smart Grids for Hyllie project, a demonstration of urban smart grid technology. The project supported the smart grid story line through its aim of demonstrating smart grid technologies in the homes of consumers, in buildings, and in energy infrastructure (Swedish Energy Agency, 2011). The project expanded the new discourse coalition to include the energy agency and helped to materialise the smart city assemblage, integrating ICT into buildings and urban infrastructure. It resulted in several new applications of ICT in Hyllie's urban energy infrastructure: new automation technology in electricity substations that would allow for more local renewable energy production; smart home technology for residents such as visualisation and remote control; and a demand response system controlling buildings as heat storage devices to shift loads in the district heating system (Swedish Energy Agency, 2016a). The demonstration of these technologies materialised the smart city assemblage, making Hyllie a climate smart-city district not just in terms of discourses and institutions, but also buildings and urban energy infrastructure, even if only some buildings adopted smart grid technologies.

In 2015, as work with the Climate Contract progressed, the city administration incorporated smart city discourses into other aspects of sustainable urban planning. For example, some planning documents began to introduce smart city story lines to issues beyond the energy system. In the comprehensive plan that described long-term development in Hyllie, the city government explained that "Energy efficient buildings will be provided with renewable energy via smart systems. The transportation facilities will be used to promote smart mobility solutions" (City of Malmö, 2015a, p. 9). Similarly, an action plan for the MEP called for "smarter resource use" using the example of Hyllie's "smart systems for energy, mobility and waste" (City of Malmö, 2015b, p. 32). These two examples introduced smart city story lines that did not refer explicitly to ICT. In contrast, the Hyllie Environmental Programme (HEP) applied results from the Smart Grids for Hyllie project to the governance of buildings. The HEP called for property developers to design buildings with urban smart grids and smart home technologies in mind; it also suggested that developers should engage with Eon as they designed the energy systems of their buildings (City of Malmö, 2015c, pp. 11-12). Through these documents and programmes, the city administration aligned more aspects of sustainable urban planning with smart city discourses and the smart city assemblage.

The final year of the Smart Grids for Hyllie project allowed Eon to extend the smart city assemblage beyond Hyllie. One of the project's most promising results was the demand response system, where Eon had demonstrated how it could send signals to buildings that guided building management systems. The demand response system made it possible to shave off district heating peak loads through a slight advance overheating, without affecting the thermal comfort of residents. The Swedish Energy Agency granted an extension to the project so that Eon could "further take the smart grid solutions developed in Hyllie to other areas and market segments, to create a system benefit beyond the level of the city district" (Swedish Energy Agency, 2015, p. 2). The extension allowed Eon to test the demand response technologies in two new settings: in the Western Harbour, where the district cooling system had production limits, and an older residential area, which suffered from bottlenecks in the district heating network. Both tests were successful; in the district cooling system, Eon even claimed that "the system benefit is already now so large that it is relevant from an operations and system perspective" (Swedish Energy Agency, 2016b, p. 12). The benefits of this technology allowed Eon to territorialise the smart city assemblage in a new way. While Eon's purpose was still to make the energy system more sustainable, it could do so outside the established practices and institutions of the sustainable city assemblage. Eon could futher materialise smart city assemblage in new places as it wished. 
After the end of the demonstration project, there were two attempts to further explore smart city technologies. In 2016, Eon and Malmö applied to the Swedish Energy Agency for a followup project. The proposed project introduced a new story line that applied smart city technologies to more aspects of urban infrastructure beyond buildings and energy systems. While the application was still framed in relation to energy, a fifth of the project budget would have been dedicated to "effective information and communication technology platforms that address real-time information" that could manage data from urban infrastructure other than the energy system (City of Malmö and Eon, 2016, p. 22). And indeed, as Eon representatives pointed out in an October 2017 workshop, Eon has the vision to become a provider of ICT infrastructures in the future. They saw the ICT installations behind the demand response system as versatile residential gateways that could be a basis for further ICT services in the future. However, the Swedish Energy Agency denied funding for this project. Instead, Eon and Malmö received funding from a European Union program focused on smart grids (FISMEP, 2016). This second project would still allow the smart city assemblage to territorialise in Malmö, but not with the same wide scope that the unsuccessful follow-up project would have provided.

\section{Graz: from eco-city to smart city}

The city of Graz is the second case of our analysis. Graz, Austria's second largest city with close to 300000 inhabitants, has since long built a strong reputation around the vision of becoming a sustainable city. It has developed a whole range of policies, institutional changes and initiatives to pursue this goal (see Rohracher \& Späth, 2014 for more details). The origins of these policies are often traced back to an increasingly bad air quality in the late 1980s (peaking in the smog winter of 1988/89) and the formation of a network of environmentally engaged people within the city administration and the city council. (Figure 2 shows a timeline of important events and policies in Graz.) Through its Local Agenda 21 Programme from the early 1990s, the Ökostadt 2000 (Eco-City 2000) environmental programme approved by the city council in 1995 and, not long after, the Municipal Energy and Climate Concept, the city moved environmental policy centre stage and implemented various programmes in the fields of sustainable transport, energy efficient buildings, industrial energy-efficiency, renewable heat supply and district heating. Graz also became the first Austrian member of the Climate Alliance of European Cities (Klimabündnis) with a greenhouse gas emission reduction target of 50\% by 2010 (compared to 1992) and was rewarded by a series of international environmental prizes. Although the emphasis on environmental policies and the branding as eco-city somewhat faded during the first decade of the new millennium, environmental ambitions and initiatives stayed on the agenda thanks to the participation of the green party in city government, in combination with institutional structures built in the 1990s, such as an independent energy agency, a strong environmental department in the municipality, and a good embedding of local actors and institutions in national and international networks. In other words, the institutionalisation of a sustainable city discourse in the form of organisations, regulations and practices has a long history, as does the eventual creation of a more homogenous and territorialised sustainable city assemblage that interweaves socio-cultural changes with material changes such an extended district heating system, a network of cycling paths or energy efficient buildings-in spite of ongoing frictions such as a stubbornly high level of particulate matter, or fights over tramline extensions and parking spaces.

The development of environmental city districts had not been in focus during the earlier phases of eco-city development. Private developers and the municipality failed in their plans to develop an ecological city district on the land surrounding an old brewery (Reininghausgründe) in 


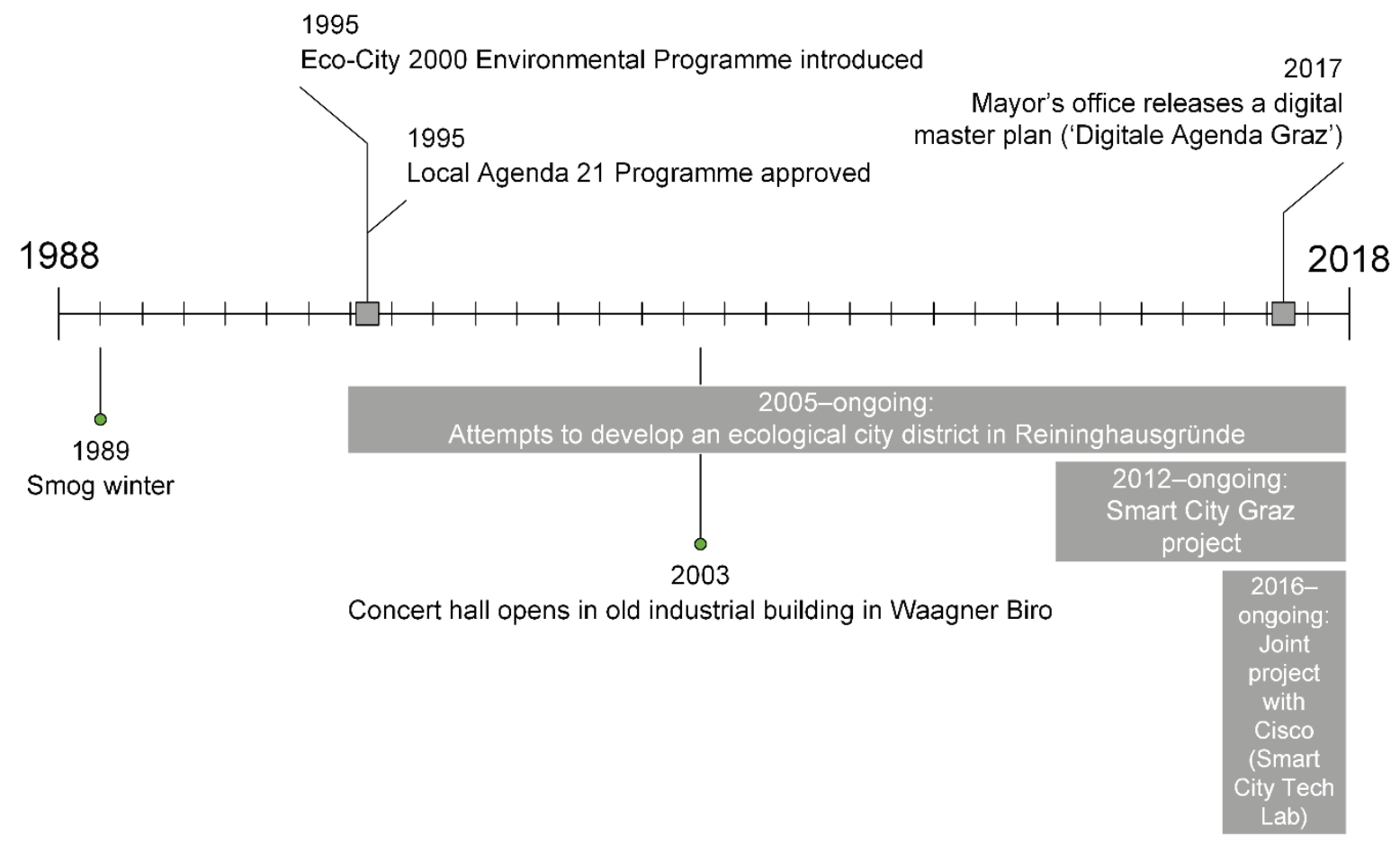

Figure 2: Timeline of important events and policies in Graz

the early 2000s, leading to conflicts about urban planning policies and the city government's capacity to enforce more fundamental changes towards sustainability. A new opportunity for a brownfield development came up in an old industrial area named Waagner Biro, centrally located near the railway station. One of the industrial buildings already had been converted to a concert hall in 2003. In the following years, the architect of the concert hall, Markus Pernthaler, who had also built other ecological landmark buildings in Graz, tried to interest developers and land owners in this area in turning the brownfield into a new city district. Main themes for the new district would be energy, mobility and social sustainability. Around the same time, a consortium led by the Graz University of Technology, and including the municipality and other local actors, took shape around the intention to submit a proposal to a new programme of the national climate fund called Smart Energy Demo - FIT for SET. The programme's intention was to make selected Austrian cities fit for participation in European Union smart city funding schemes and promote urban smart city regions with the vision to turn them into a zero emission city.

In a collaborative effort between researchers, the municipality and developers, the consortium managed to receive more than $€ 4$ million for a smart city pilot project in the Waagner Biro district. The plan was to develop a showcase around a range of innovative energy technologies (e.g. new semi-transparent building-integrated photovoltaics; citizen owned photovoltaic plants on rooftops; integration of different forms of decentralised renewable heat generation; district energy management) and mobility concepts (focusing on electro-mobility and mobility management systems). In line with the original idea, strong emphasis was still put on social sustainability issues, such as a social mix of inhabitants thanks to affordable flats, citizen participation strategies (organised by a new citizen office, CityLab Graz), a mix of work and leisure opportunities in the district, and emphasis on public green spaces. These activities were embedded in a broader Vision Graz 2050 with targets such as $100 \%$ local renewable energy supply. 
To a large extent we can thus see the development of the Smart City Graz district as an extension of the dominant sustainable city assemblage. The overall idea was moving towards a zeroemission city and most of the implemented elements had a focus on greener energy or mobility systems, as well as the creation of a liveable urban space with a high involvement of residents. The idea of 'smartness' and the emphasis on ICT solutions in infrastructure management played an important role in branding this city district and linking it to national and European Union research strategies promoting smart cities, but created new tensions in the dynamic process of assembling the sustainable city.

Most of the actors firmly embedded in the sustainable city assemblage did voice some concern about the framing of their sustainable urban development plans as smart city. For one, they were aware of the danger of putting forward a technocentric approach using a smart city discourse, even if not only focusing on ICT, but other technological solutions in energy or mobility. The head of the municipality's environmental department pointed to the tendency of smart city proponents to focus on rather self-contained city district solutions such as local energy generation, with little regard for the overall infrastructure development of the city or a balanced urban planning approach beyond the new district. Moreover, when asked about the role of ICT in particular, the proponents of Smart City Graz did acknowledge that those technologies have played an increased role, whether as communication platforms or in the management of infrastructures, but they rather consistently point to many unresolved problems around data security and the danger of for-profit companies owning and managing personal or public data. Most of the interviewees went on at length to point out how they would try to avoid these traps and go beyond purely technological solutions for sustainability. These tensions point to some fear of deterritorialising sustainability through new rationalities and priorities of an emerging smart city assemblage.

Actors committed to Graz as a sustainable city showed different strategies in their attempts to keep the sustainable city assemblage homogenous and territorialised. One move was to reconcile the national and internal smart city discourse with the local green city district by attempting to redefine 'smart'. The architect coordinating the smart city project was keen to point out how 'smart', in the context of this project, rather related to resource efficiency and an integrated perspective on sustainable urban development. A second strategy was the further integration of ICT in assembling the sustainable city. The head of the environmental department for example expressed his support for new air pollution sensors and environmental monitoring schemes and acknowledged the increasing role of ICT in managing the decentralised energy generation in the district. These attempts to make ICT part of achieving more sustainable cities are also reflected at the national and European level, where smart city programmes originally emerged from the European Commission's Strategic Energy Technologies Plan and are still rooted in energy and sustainability programmes rather than information technology initiatives. Nevertheless, there remained in Graz a certain unease and tension regarding the consequences of an increased ICT focus of sustainable cities, despite all attempts to keep the sustainable city assemblage homogenous.

And indeed, the development of the new smart city district also became part of territorialising the smart city assemblage that was dominated much more by ICT. Information technologies and digitalisation have long been in the focus of economic and innovation policies, partly as an infrastructure for the further modernisation and competitiveness of the local economy, and partly as a growing economic sector of its own. Proponents of urban economic development used the smart city discourse, with its emphasis on ICT, to increase their influence over urban development in Graz. As the green city councillor pointed out, the property department (under the political responsibility of the mayor), took the chance to play a much stronger role in shaping the district development than it did with sustainability-focused projects that were driven by other 
actors. In connection to the smart city project, the mayor's office developed a digital agenda for the City of Graz and pushed for a stronger integration of the smart city project in ICT-led developments. As the green councillor expressed, these policies were characterised by very little regard for sustainability and focused rather on economic development and the promotion of corporate actors. In parallel to the development of the new district, the mayor's office developed a digital master plan as a roadmap to a green, digital city and established a City Tech Lab of the City of Graz that aimed to attract ICT-related companies and to carry out "pilot projects for the smart, digital city of the future." To date collaboration contracts have been signed with IBM, Cisco and NTS, a data management and data network infrastructure company.

In particular, a joint project with the smart city arm of Cisco has already come a long way and was controversially discussed in the interviews with sustainable city proponents. The plan is to install new LED street lighting systems, with each street light equipped with up to 40 different sensors that measure air pollutants and road surface conditions, and in the longer term potentially generating information about traffic conditions such as free parking spaces or traffic flow. Cisco would provide the traffic lights for free in exchange for access to or ownership of the data generated by the sensors. Obviously, such a development is highly controversial and has alerted a range of municipal actors. The municipal utilities have also considered their potential role in such a system, for example as a trusted manager for the data generated. The current last step in the smart city project in Graz is a funding proposal to the EU's Horizon 2020 research framework programme. This project would comprise the further development of smart city ideas in the Waagner Biro district and would put much more emphasis on ICT solutions - in line with the call criteria for smart city projects in the Horizon 2020 programme. One of the planned pilot projects is a test area for the aforementioned Cisco street lighting sensors in the Waagner Biro district. We can thus indeed speak of a process of gradual territorialisation of a smart city assemblage: a configuration of a few ICT pilot projects that introduce new technologies into urban infrastructure; the emergence of new networks of municipal actors such as property department, closely coupled to corporate actors (Cisco, IBM, etc.); and an agenda of economic development and advancing the smart, digital city of the future.

The new smart city district is simultaneously part of both the sustainable city and the smart city assemblage, and assumes different meanings within these assemblages. The co-existence of the two assemblages, however, does create tensions and conflicts and raises concerns particularly among sustainable city proponents about urban development driven much more by economic interests and around techno-centric ideas of urban futures.

\section{Discussion}

What we have seen in both cases, in both Malmö and Graz, was a gradual territorialisation of smart city assemblages. The introduction of smart city discourses was not simply a re-labelling of existing initiatives (Crivello, 2015) nor a branding exercise without any change in practice (Wiig, 2016). Rather, there have been changes in institutions and socio-material practices, particularly through initiatives and projects focused on ICT such as smart grids and sensor networks.

However, is this a shift from sustainable to smart? Does the shift imply a weakening of sustainable city ambitions? It is not self-evident that the territorialisation of a smart city assemblage destabilises existing sustainable city assemblages. Our analysis confirms that sustainable city and smart city discourses are malleable and flexible, and their importance for urban governance is not only limited to their direct content. As has been observed in regard to sustainable cities, an important effect of the discourse is the facilitation of "collaborative governance for infrastructural investment," even if those investments in practice might only be loosely related to sustainability 
(Tahvilzadeh et al., 2017). Similarly, smart city discourses are appealing not just for their technological solutions, but also because their vagueness provides political opportunities and allows for collaborative governance (Haarstad, 2017). In this respect both discourses might serve to enable political decisions about infrastructural investments. Whether the shift to smart also involves a shift from sustainability is a question of whether the territorialisation of a smart city assemblage involves a deterritorialisation of the corresponding sustainable city assemblage.

In our cases we can identify two ideal-typical dynamics of how these two assemblages interact with each other and reorganise visions and practices of urban development: appropriation and colonisation. We define appropriation as the mutual territorialisation of assemblages. One assemblage attempts to territorialise itself by incorporating components of a second assemblage. The logic of appropriation does not support the notion of a shift from one assemblage to another, as it rather refers to an extension of the heterogeneous network and meanings of an existing assemblage. In contrast, we define colonisation as the territorialisation of one assemblage that leads to the deterritorialisation of another assemblage. It is colonisation rather than appropriation that supports the notion of a shift from sustainable to smart. Under colonisation dynamics, a sustainable city assemblage might still exist in terms of discourses and socio-material elements, but increasing parts of it adhere to the logics of ICT use, corporate influence and economic growth that are part of a smart city assemblage.

The appropriation dynamics can clearly be seen in the early phases of smart city development in both cities. In Graz, the coalition of actors driving the development of the new smart city district were clearly rooted in Graz's sustainable city assemblage. This assemblage consisted of the eco-city vision of Graz, which had been a guiding vision for urban politics for many years, as well as the vision's strong institutional and actor base in the municipality. Key actors that supported the eco-city vision drew on smart city discourses to provide new branding and attract national funding that would help them to further territorialise the sustainable city assemblage. They actively appropriated smart city discourses as well as the use of ICT, but adapted them to existing practices of sustainable urban planning. The actors behind the Waagner Biro district argued that their understanding of smart was different and followed traditional ideals of sustainable development, enriched by the possibilities of ICT integration. At the same time, connotations of smart cities as techno-centric and a threat to data integrity were actively disputed as part of a different smart city assemblage. Concerns about such a smart city assemblage becoming dominant with all its implications for urban developments were thus present, despite strategies to appropriate its main components within a sustainable city assemblage.

In Malmö, the appropriation logic also dominated as existing actors helped to territorialise the smart city discourse. The Climate Contract for Hyllie was rooted in the sustainable city assemblage, particularly in how the Climate Contract referenced the Malmö Environmental Programme and the city government's long-term climate goals. The difference in Malmö, compared to Graz, is that this territorialisation also involved changes to institutions and socio-material practices. The Climate Contract established institutions in which Eon took a larger role than before in sustainable city governance. The Smart Grids for Hyllie project introduced more ICT into buildings and urban energy infrastructure. Discursively, the city administration appropriated smart city story lines about mobility and waste. But as with Graz, the early process of creating an alternative ICTdominated smart city assemblage did not yet destabilise the sustainable city assemblage. The sustainable city assemblage maintained a homogeneous repertoire including interdependent components such as the city government's climate goals and the developer dialogues used to encourage more sustainable buildings in Hyllie. 
Recent developments in Graz suggest that such an ICT-driven smart city assemblage might yet become dominant and colonise the co-existing assemblage of a sustainable city. The smart city is continuing to territorialise through projects such as the new proposal for European Union funding, which focuses on ICT-driven developments such as the monitoring of traffic flows and the implementation of various services driven by open data. These technologies might define the agenda of the new district much more than sustainability principles. Along the same lines, new actor coalitions within the smart city assemblage might be able to set priorities in urban development. These actors include ICT firms with a main focus to gain access to different types of data that in the long term might prove commercially profitable, and municipal actors with a main interest in urban economic development and modernisation. The increasing focus on ICT, combined with new actor coalitions, represents a territorialisation of the smart city assemblage that simultaneously deterritorialises the sustainable city assemblage. Sustainability issues might still play a significant role in the European Union-funded project, but possibly only where they have a good fit with smart city discourses. And even though sustainable urban development discourses have themselves been riddled by disputes about whether they have become too instrumental for an economic growth orientation, the colonisation represents a shift from sustainable to smart in which ICT solutions and economic growth might become even more hegemonic.

In Malmö, we also identify a dynamics of colonisation in Eon's increasing influence. Recent developments in the smart city assemblage prioritise corporate control and investments in ICT. Eon and Malmö's application for a follow-up project would have led to more focus on ICT in Hyllie, such as a data platform for all urban infrastructure. Had the project been funded, it could have destabilised the sustainable city assemblage by reshaping technologies according to other urban infrastructures, other actors and other policy goals. Eon makes no secret that they see a larger role for the company in urban infrastructure, eventually including ICT infrastructures and services. Another sign of colonisation by the smart city assemblage is Eon's increasing capacity to, on its own, introduce smart grid technology into urban energy infrastructure. Urban smart grids developed into a technology with commercial potential but without any clear oversight role from the city government. With Eon's position in the urban energy system and the potential of urban smart grids, the smart city assemblage can extend according to Eon's commercial needs rather than the city government's climate goals. The smart city assemblage might further redefine buildings in terms of their potential to shift energy loads in a smart grid rather than the reduction of overall energy use (Parks, 2019). The sustainable city assemblage would become more deterritorialised, making it less able to influence the development of urban smart grids in a way that is compatible with the city government's climate goals.

Though a tendency toward more ICT-driven developments is visible in both Graz and Malmö, the dynamics of colonisation play out differently due to their distinct histories, planning cultures and institutional contexts. One difference concerns the current structures of infrastructure governance. In Malmö, electricity and district heating networks are owned by Eon, which collaborates closely with the municipality. In contrast, utilities and infrastructures in Graz are still to a larger extent in public hands. While it is for-profit companies that push the smart city assemblages to colonise the sustainable city assemblages in both cities, in Malmö that company is also the energy utility, while in Graz those companies such as Cisco do not have a historical role in urban infrastructure. Even if such a colonisation does occur, the energy utilities in Graz are seen as some sort of trusted public middleman who could, for example, handle sensitive data instead of for-profit companies. In Malmö, there is no municipally owned organisation who would be the obvious candidate for such a role, and the result could be that control of the data more easily falls to a for-profit company. 


\section{Conclusions}

Our aim in this article has been to zoom in on the dynamics of a shift from sustainable to smart in cities with well-known traditions of sustainable urban development. Does the shift to smart consist of a re-branding of sustainability interventions without much change in practice? Or do smart city discourses reflect a re-assembling of socio-material relations in cities that qualitatively changes existing practices of sustainable urban planning and prioritises other interests and goals? The two cities of Malmö and Graz provide evidence of a shift to smart through ongoing discursive and sociomaterial changes. The shift is not merely a re-branding of existing initiatives, but neither is it a discrete shift from one coherent package of socio-material practices to another. There does not seem to be any straightforward way to implement an integrated concept of smart-sustainable cities, as some authors suggest (Bibri and Krogstie, 2017; Höjer and Wangel, 2015). Since discourses of sustainable cities and smart cities are both characterised by a high level of vagueness and interpretative flexibility, integrating them is a process influenced by historical backgrounds, actor configurations and institutional contexts.

The notion of co-existing assemblages of sustainable and smart cities, as well as the dynamics of appropriation and colonisation, contributes to understanding how the re-assembling of socio-material relations takes place. Some previous studies have noted that smart city initiatives lead to rather little ICT in urban energy infrastructure, and that the biggest effects of these initiatives are rather new actor coalitions or the introduction of for-profit companies into urban infrastructure management (Haarstad, 2017; March and Ribera-Fumaz, 2016). This article does not contradict those studies, but colonisation denotes a process in which these new actor coalitions lead to new institutions and socio-material practices where ICT takes a much larger role in urban planning. What is perhaps most important in understanding the shift to smart is the conditions that allow for a change in dynamics from appropriation to colonisation. The challenge in understanding the shift is that it does not take place through explicit controversy between two discourse coalitions. The cases of Malmö and Graz both show how appropriation is facilitated though national funding schemes through the encouragement of actor coalitions that "blur distinctions between public and private authority while creating new forms of political space" (McLean et al., 2016, p. 3260). Colonisation builds on these actor coalitions and takes place through "ongoing negotiation, a quiet contestation, compromise and attrition of different positions" (Bulkeley et al., 2016b, p. 1724). But whether the process of colonisation leads to a hegemonic relation of smart over sustainable, or to more benign constellations of co-existence, is still an open question.

To better understand the implications of the shift to smart requires careful empirical studies of the changes to institutions and socio-material practices that result from the introduction of smart city discourses. The strength of the assemblage perspective is in acknowledging the multiplicity of co-existing assemblages and in the constant work required to build and stabilise these heterogeneous networks. This article distinguishes two assemblages in each case-sustainable and smart-but other studies might differentiate even more "urban green assemblages" (Blok, 2013). Using an assemblage perspective, we have shown that it is not justified to criticise smart city discourses as meaningless brands or empty signifiers that have no influence on cities. Nor is it fair to paint all smart city discourses in a negative light; our analysis shows that actors involved in the practice of sustainable urban planning do see some potential in the introduction of ICT to urban energy infrastructure. It is also worth a reminder that sustainable city discourses have long been contested and that their translation into institutions and socio-material practices of urban planning has not solved all urban environmental problems. Only time will tell whether smart city assemblages will colonise sustainability discourses and rob them of their critical potential, or whether mutual 
appropriation of smart and sustainable assemblages will result in adapted forms of smartness as part of sustainable urban change processes. 


\section{References}

Bibri, S.E., Krogstie, J., 2017. On the social shaping dimensions of smart sustainable cities: A study in science, technology, and society. Sustain. Cities Soc. 29, 219-246. https://doi.org/10.1016/j.scs.2016.11.004

Blok, A., 2013. Urban Green Assemblages: An ANT View on Sustainable City Building Projects. Sci. Technol. Stud. 26, 5-24.

Bulkeley, H., Betsill, M., 2005. Rethinking Sustainable Cities: Multilevel Governance and the "Urban" Politics of Climate Change. Environ. Polit. 14, 42-63. https://doi.org/10.1080/0964401042000310178

Bulkeley, H., Castán Broto, V., Maassen, A., 2014. Low-carbon Transitions and the Reconfiguration of Urban Infrastructure. Urban Stud. 51, 1471-1486. https://doi.org/10.1177/0042098013500089

Bulkeley, H., Kern, K., 2006. Local Government and the Governing of Climate Change in Germany and the UK. Urban Stud. 43, 2237-2259. https://doi.org/10.1080/00420980600936491

Bulkeley, H., McGuirk, P.M., Dowling, R., 2016. Making a smart city for the smart grid? The urban material politics of actualising smart electricity networks. Environ. Plan. Econ. Space 48, 1709-1726. https://doi.org/10.1177/0308518X16648152

City of Malmö, 2015a. Comprehensive Plan for Southern Hyllie (Proposal for public comments).

City of Malmö, 2015b. Action Plan for the Environmental Programme: Prioritised work in the City of Malmö, 2015-2018.

City of Malmö, 2015c. Hyllie Environmental Programme.

City of Malmö, 2009. Environmental Programme for the City of Malmö, 2009-2020.

City of Malmö, 2002a. Quality programme for spatial plan 4537.

City of Malmö, 2002b. Ecologically Sustainable Construction in Malmö', part 1: policy [Ekologiskt hållbart byggande i Malmö, del 1: policy].

City of Malmö, City of Lund, Lund University, 2009. Environmental Construction Programme for Southern Sweden.

City of Malmö, Eon, 2016. Application - Smart grids in Hyllie phase II 2017-2019.

City of Malmö, Eon, VA Syd, 2011. Climate Contract for Hyllie.

Cowley, R., Joss, S., Dayot, Y., 2017. The smart city and its publics: insights from across six UK cities. Urban Res. Pract. 0, 1-25. https://doi.org/10.1080/17535069.2017.1293150

Crivello, S., 2015. Urban Policy Mobilities: The Case of Turin as a Smart City. Eur. Plan. Stud. 23, 909921. https://doi.org/10.1080/09654313.2014.891568

de Jong, M., Joss, S., Schraven, D., Zhan, C., Weijnen, M., 2015. Sustainable-smart-resilient-low carbon-eco-knowledge cities; making sense of a multitude of concepts promoting sustainable urbanization. J. Clean. Prod. 109, 25-38. https://doi.org/10.1016/j.jclepro.2015.02.004

DeLanda, M., 2016. Assemblage theory. Edinburgh University Press, Edinburgh.

DeLanda, M., 2006. A new philosophy of society : assemblage theory and social complexity. Continuum, London ;

Dóci, G., Vasileiadou, E., Petersen, A.C., 2015. Exploring the transition potential of renewable energy communities. Futures 66, 85-95. https://doi.org/10.1016/j.futures.2015.01.002

European Parliament, 2014. Mapping Smart Cities in the EU. Directorate General for Internal Policies, Policy Deparment A: Economic and Scientific Policy.

Farías, I., 2010. Decentering the object of urban studies, in: Bender, T., Farías, I. (Eds.), Urban Assemblages: How Actor-Network Theory Changes Urban Studies. Routledge, London; New York, pp. 1-24.

FISMEP, 2016. Project application: FIWARE for Smart Energy Platform.

Gabrys, J., 2014. Programming environments: environmentality and citizen sensing in the smart city. Environ. Plan. Soc. Space 32, 30-48. https://doi.org/10.1068/d16812 
Green, A., 2006. Hållbar energianvändning i svensk stadsplanering: från visioner till uppföljning av Hammarby Sjöstad och Västra Hamnen. Tema Teknik och social förändring, Linköpings universitet, Linköping.

Haarstad, H., 2017. Constructing the sustainable city: examining the role of sustainability in the 'smart city' discourse. J. Environ. Policy Plan. 19, 423-437. https://doi.org/10.1080/1523908X.2016.1245610

Hajer, M., 2015. On being smart about cities, in: Allen, A., Swilling, M., Lampis, A. (Eds.), Untamed Urbanisms. Routledge, Abingdon, Oxon ; New York, NY.

Hajer, M., 1997. The Politics of Environmental Discourse. Oxford University Press. https://doi.org/10.1093/019829333X.001.0001

Hodson, M., Marvin, S., Bulkeley, H., 2013. The Intermediary Organisation of Low Carbon Cities: A Comparative Analysis of Transitions in Greater London and Greater Manchester. Urban Stud. 50, 1403-1422. https://doi.org/10.1177/0042098013480967

Höjer, M., Wangel, J., 2015. Smart Sustainable Cities: Definition and Challenges, in: Hilty, L.M., Aebischer, B. (Eds.), ICT Innovations for Sustainability, Advances in Intelligent Systems and Computing. Springer International Publishing, pp. 333-349.

Kitchin, R., 2015. Making sense of smart cities: addressing present shortcomings. Camb. J. Reg. Econ. Soc. 8, 131-136. https://doi.org/10.1093/cjres/rsu027

Kitchin, R., 2014. The real-time city? Big data and smart urbanism. GeoJournal 79, 1-14. https://doi.org/10.1007/s10708-013-9516-8

Long, J., 2016. Constructing the narrative of the sustainability fix: Sustainability, social justice and representation in Austin, TX. Urban Stud. 53, 149-172. https://doi.org/10.1177/0042098014560501

March, H., Ribera-Fumaz, R., 2016. Smart contradictions: The politics of making Barcelona a Selfsufficient city. Eur. Urban Reg. Stud. 23, 816-830. https://doi.org/10.1177/0969776414554488

Martin, C.J., Evans, J., Karvonen, A., 2018. Smart and sustainable? Five tensions in the visions and practices of the smart-sustainable city in Europe and North America. Technol. Forecast. Soc. Change. https://doi.org/10.1016/j.techfore.2018.01.005

McCann, E., 2011. Urban Policy Mobilities and Global Circuits of Knowledge: Toward a Research Agenda. Ann. Assoc. Am. Geogr. 101, 107-130. https://doi.org/10.1080/00045608.2010.520219

McLean, A., Bulkeley, H., Crang, M., 2016. Negotiating the urban smart grid: Socio-technical experimentation in the city of Austin. Urban Stud. 53, 3246-3263. https://doi.org/10.1177/0042098015612984

Mneimneh, F., Srour, I., Kaysi, I., Harb, M., 2017. Eco-City Projects: Incorporating Sustainability Requirements during Pre-Project Planning. J. Urban Technol. 24, 47-74. https://doi.org/10.1080/10630732.2016.1175828

Mol, A., 2002. The Body Multiple: Ontology in Medical Practice. Duke University Press Books, Durham.

Parks, D. (2019). Energy efficiency left behind? Policy assemblages in Sweden's most climate-smart city. European Planning Studies, 27(2), 318-335. https://doi.org/10.1080/09654313.2018.1455807

Quitzau, M.-B., Jensen, J.S., Elle, M., Hoffmann, B., 2013. Sustainable urban regime adjustments. J. Clean. Prod., Special Issue: Advancing sustainable urban transformation 50, 140-147. https://doi.org/10.1016/j.jclepro.2012.11.042

Rohracher, H., Späth, P., 2014. The Interplay of Urban Energy Policy and Socio-technical Transitions: The Eco-cities of Graz and Freiburg in Retrospect. Urban Stud. 51, 1415-1431. https://doi.org/10.1177/0042098013500360 
Smedby, N., 2016. Assessing local governance experiments for building energy efficiency - the case of Malmö, Sweden. Environ. Plan. C Gov. Policy 34, 299-319. https://doi.org/10.1177/0263774X15614176

Smedby, N., Neij, L., 2013. Experiences in urban governance for sustainability: the Constructive Dialogue in Swedish municipalities. J. Clean. Prod. 50, 148-158. https://doi.org/10.1016/j.jclepro.2012.11.044

Söderström, O., Paasche, T., Klauser, F., 2014. Smart cities as corporate storytelling. City 18, 307320. https://doi.org/10.1080/13604813.2014.906716

Strengers, Y., 2013. Smart energy technologies in everyday life: smart utopia? Palgrave Macmillan, New York.

Swedish Energy Agency, 2016a. Final report: Smart grids for a sustainable energy system in Hyllie.

Swedish Energy Agency, 2016b. Final report: Smart grids for a sustainable energy system in Hyllie. Attachment 4.

Swedish Energy Agency, 2015. Decision about Extension and Modification of Activities.

Swedish Energy Agency, 2011. Project decision: Smart grids for a sustainable energy system in Hyllie.

Tahvilzadeh, N., Montin, S., Cullberg, M., 2017. Functions of sustainability: exploring what urban sustainability policy discourse "does" in the Gothenburg Metropolitan Area. Local Environ. 0, 1-20. https://doi.org/10.1080/13549839.2017.1320538

Vanolo, A., 2014. Smartmentality: The Smart City as Disciplinary Strategy. Urban Stud. 51, 883-898. https://doi.org/10.1177/0042098013494427

Wiig, A., 2016. The empty rhetoric of the smart city: from digital inclusion to economic promotion in Philadelphia. Urban Geogr. 37, 535-553. https://doi.org/10.1080/02723638.2015.1065686

Williams, J., 2018. Assembling the water factory: Seawater desalination and the techno-politics of water privatisation in the San Diego-Tijuana metropolitan region. Geoforum 93, 32-39. https://doi.org/10.1016/j.geoforum.2018.04.022

Wretling, V., Gunnarsson-Östling, U., Hörnberg, C., Balfors, B., 2018. Strategic municipal energy planning in Sweden - Examining current energy planning practice and its influence on comprehensive planning. Energy Policy 113, 688-700.

https://doi.org/10.1016/j.enpol.2017.11.006 